Ward, S. (2017) 'Searching for effective and democratic town planning: the international travels of Sir Ernest Simon, 1936-1943', Planning Perspectives

DOI: https://doi.org/10.1080/02665433.2017.1286516

This document is the authors' Accepted Manuscript.

License: https://creativecommons.org/licenses/by-nc-nd/4.0

Available from RADAR: https://radar.brookes.ac.uk/radar/items/54356585-45c9-4097-9e5e-0b186ada7ae4/1/

Copyright (C) and Moral Rights are retained by the author(s) and/ or other copyright owners unless otherwise waved in a license stated or linked to above. A copy can be downloaded for personal non-commercial research or study, without prior permission or charge. This item cannot be reproduced or quoted extensively from without first obtaining permission in writing from the copyright holder(s). The content must not be changed in any way or sold commercially in any format or medium without the formal permission of the copyright holders. 


\section{Searching for effective and democratic town planning: the international travels of Sir Ernest Simon, 1936-1943}

Stephen V. Ward, School of the Built Environment, Oxford Brookes University, Oxford OX3 OBP, UK.svward@brookes.ac.uk

\section{Introduction}

Town planning can never be treated effectively as a thing by itself. I believe that fine planning in this country can only come as part of a new spirit, a revivified democracy determined to build a new civilisation... We all of us believe here, whatever political party we may belong to, that democracy is the best form of government. But we are forced to admit with regret that in this matter of town planning it is falling behind not only Russia...but also other countries under dictatorships...I firmly believe that if British democracy makes up its mind it can, within the next two generations, make the cities of England once more places of beauty in which it is good to be alive. ${ }^{1}$

With these stirring words, the well-known Manchester reformer and businessman Sir Ernest Simon closed his address to the Town and Country Planning Summer School in early September 1937. He had been comparing town planning in Moscow and Manchester, largely to the detriment of his home city. The speech had first been delivered a month earlier to the Liberal Summer School. ${ }^{2}$ Later in the year it was published, its central question now starkly dramatised in a new subtitle, 'Moscow or Manchester?'3

Its underlying theme was already an important progressive reformist concern in Britain in the 1930s and 1940s - how to develop an approach to planning that was both effective and democratic. This concern grew from what many saw as the weaknesses of parliamentary democracy in tackling the major challenges of the interwar years, in stark contrast to the seeming decisiveness of totalitarian regimes. Some who shared these concerns themselves moved to the extreme left or right. But a growing number of more democratically-disposed reformers sought some kind of middle way, between unfettered capitalism and the centrally planned approach of the dictatorships. ${ }^{4}$ There were several varieties of this progressive 'middle opinion' in the 1930s which each sought to use their idea of planning to shape wider economic and social development. War added greatly to the salience of these ideas, especially those variants that saw a larger role for state intervention.

A distinct aspect of this wider interest was the mounting pressure for a bolder and more comprehensive form of town and regional planning, more closely integrated with social and economic development. Ernest Simon was both a significant proponent of these specific concerns and an active member of the wider planning movement. Although his experience was rooted in Britain, especially Manchester, Simon also drew on several international examples. His international knowledge came from fact-finding visits made in a voluntary capacity to the Soviet Union (1936), the Nordic countries and Switzerland (1938) and, in an official capacity, to the United States (1942-3). Although he had a particular interest in 
housing and town planning, the themes he investigated in these countries ranged widely across the fields of governance, especially so in the Nordic Countries and Switzerland. This article is however especially concerned with his town and regional planning interests where, in those particular countries, he concentrated on Stockholm and Zurich. In the Soviet Union, as already noted, his concern was Moscow although, during his longest tour, to the United States, he visited many cities and saw some regional development planning.

These visits form the subject of this article, based on the detailed, largely handwritten, notes he kept during these trips, now held in the Ernest Simon papers at Manchester Central Library. Also used are his subsequent books, articles and lectures, in which he distilled what he saw as the lessons of these countries for Britain. This study is also therefore an example of how urban policy knowledge circulates internationally and externally acquired knowledge can inform and affect national and local debates about policy formulation. This more general theme therefore links it to a growing body of work within political science, urban geography and planning theory, as well as more empirical studies undertaken by other planning historians. ${ }^{5}$

In various ways, recent work has helped understand how foreign planning and other urban policy practices are discovered and wider value attributed to this knowledge. It is increasingly acknowledged that the resultant circulation of planning knowledge may be only partially an objective and rational process of learning. Chance or personal factors and various socially and culturally-constructed imaginings of other places might well affect what is discovered and subsequently adapted (or not) within new settings. These background considerations help to frame this investigation of these visits and what flowed from them, beginning with the central figure in the story.

\section{Sir Ernest Simon}

Ernest Emil Darwin Simon (Figure 1) was a Manchester man, born in 1879 into an industrialist family originally from Prussian Silesia. ${ }^{6}$ His father Henry had arrived in Manchester via Zurich (where he had a brother) in 1860. Within a few years Henry had founded what later became the Simon Engineering Group. When his father died in 1899, the young Ernest was still at University, studying engineering. But, after graduating, he soon took increasing charge of the family companies. Like his father, Ernest was a hard-working and successful businessman, more so than either his elder half-brother or three younger brothers. The latter were all killed during the First World War, making him head of his wider family before he was forty.

Despite these important family and business responsibilities, he soon entered public life, joining Manchester City Council in 1912 and remaining a member until 1925. His business experience quickly brought him important municipal roles and he later served as Lord Mayor. He was also a Liberal Member of Parliament in 1923-4 and 1929-31 and was knighted in 1932. At both local and national levels, his main interests were initially public health but increasingly focused on housing and town planning. He soon became a nationally recognised expert who lectured and wrote extensively on these themes, largely favouring garden city 
ideas and cottage-style housing. He played an important formative role in Manchester's great municipal garden city project at Wythenshawe, towards which he gifted a sizeable parkland estate and historic house. When he was ennobled in 1947, he became Lord Simon of Wythenshawe.

With his wife, Ernest Simon played many roles in Manchester's intellectual, cultural and political life, as leader, patron and benefactor. His political perspective was progressive, initially expressed in Liberalism, combined with a humanist agnosticism that bore no trace of the Simon family's Jewish roots. ${ }^{7}$ A family friend of the famous editor of the Manchester Guardian, C. P. Scott, he championed the city's higher education, supported the Halle Orchestra and much else of its cultural life. ${ }^{8}$ These intense local commitments did not mean, however, that he ignored other experiences. His family background connected him to continental Europe, especially but not exclusively the German-speaking countries, while family wealth allowed impressive foreign holidays. More purposefully, he had also by 1914 voyaged across the globe on behalf of the Simon companies.

Yet his most formative experience outside Manchester lay within Britain. From 1909 he became deeply involved in the London-based Fabian movement and was a great admirer of its leaders, Sidney and Beatrice Webb. For their part, they welcomed this intelligent and progressively-minded young man who combined great success in business with a commitment to enlightened governmental intervention to promote human welfare. The Webbs saw Fabianism as promoting an alternative to the unbridled economic liberalism of the nineteenth century 'Manchester School' and Ernest Simon was well placed to help promote that shift. His wealth was also useful in supporting their favoured causes. For some years, however, his objections to wholesale nationalisation prevented him following them into the Labour Party. But he was never primarily a party political figure and was always willing to work across party boundaries. This was particularly so in the period here considered when, though not amongst the main leaders of the wider planning movement, he identified closely with 'middle opinion' groups and causes. ${ }^{9}$ During those years, meanwhile, he drifted away from Liberalism which was declining as an effective party political force and in 1946 joined the Labour Party.

This shift owed much to his wife and partner in public life, Shena Dorothy Simon. ${ }^{10}$ They had met through their Fabian involvements and many compared them to the Webbs, with whom they were good friends. Like Ernest, Shena had a wealthy family background and, though not from Manchester, immersed herself in its public affairs from what was originally a Liberal and humanistic agnostic standpoint before she joined Labour in 1935. As a member of the city council 1924-33, she contributed significantly to Wythenshawe's early development and to Manchester's educational provision. Despite her own full life of public service, she accompanied Ernest on some international visits and undoubtedly influenced the conclusions he drew from them.

\section{To Moscow}

The first one came in September 1936 and produced a notable book, Moscow in the Making (1937). ${ }^{11}$ Soviet visits had become increasingly popular in Britain during the 1930s, involving 
a variety of organisations. ${ }^{12}$ Some were overtly party political or associated with the wider labour movement. A growing number, however, were arranged through the Society for Cultural Relations between the British Commonwealth and the USSR (known as the SCR), an Anglo-Soviet friendship society sympathetic to the Soviet Union founded in $1924 .{ }^{13}$ There was also an increasing interest from the tourism industry with some travel agents specialising in this growing market. On the Soviet side two bodies were also especially important. ${ }^{14}$ VOKS (Vsesoiuznoe Obshchestvo Kul'turnoi Sviazi s zagranitsei - All-Union Society for Cultural Relations with Foreign Countries) had been founded in 1925 to promote and inform external interest in the Soviet Union, including fostering a network of national friendship societies. This essentially propagandist concern was increasingly supplemented by a desire to earn foreign currency and Intourist, the Soviet travel agency, was founded in 1929.

The Simon visit had much in common with other Soviet visits during these years. ${ }^{15}$ Lasting four weeks, the normal duration of a Soviet visa, it was arranged by the SCR, with, in this case, personal facilitation from the Soviet Ambassador in London, Ivan Maisky. VOKS and Intourist gave their usual assistance at the Moscow end, identifying many specific people to interview and sites to visit and providing interpreters. ${ }^{16}$ Ernest Simon led the group and was its main originator and funder. ${ }^{17} \mathrm{He}$ was joined by Shena, William A. Robson, an expert on constitutional law and local government from the London School of Economics and John Jewkes, an industrial and regional economist from the University of Manchester. Ernest knew Robson from their Fabian involvements in London and Jewkes (not a Fabian adherent) from public and business life in Manchester. Although not involved in writing the book, the Simons' eldest son, Roger, and Ernest's nephew Michael also accompanied them. ${ }^{18}$ Michael took detailed factual notes at many interviews, supplementing Ernest's own which focused on major impressions.

The group examined the work of the Mossoviet, the Moscow City Government, in the wake of the great 1935 general plan for the reconstruction of the Russian capital. ${ }^{19}$ As might be expected, the whole approach was dominated by Fabian thinking and especially by Sidney and Beatrice Webb. In this case, the primary spur came from the latter's two volume work Soviet Communism: A New Civilisation? published in $1935 .{ }^{20}$ Despite its comprehensive nature, however, this major work left much untold about Soviet city governance, a gap Ernest Simon hoped to fill. The Webbs also gave encouragement and made many detailed suggestions. $^{21}$

The party landed at Leningrad on Friday $28^{\text {th }}$ August 1936, travelling next day to Moscow. ${ }^{22}$ After some sightseeing, an intense few weeks of interviews and visits began on the 31 st. Ernest Simon's loose leaf diary of the Moscow visit, which includes Michael Simon's own notes, records meetings with approximately 38 people. Of these, around 20 (some were not named) were Soviet officials of varying importance. The named interviewees, the majority, were impressive, however, including several senior members and professional officials of the Mossoviet responsible for planning and development. They included the chair and chief architect of the city planning commission (Mel'bard and Chernichev, along with the latter's assistants Sashavski and Orleanski). ${ }^{23}$ (Not interviewed, however, was Mossoviet leader, Bulganin, who was coincidentally visiting London and Paris. $)^{24}$ Ernest also met the leaders of 
important Trusts responsible for water supply (Shternberg) building (Shurigin) and other aspects of Moscow's development. ${ }^{25}$ Others were senior figures of the state planning agency, Gosplan (Mezhlauk, Lauer and Uchakov), and Narkomkhoz, the Commissariat of Municipal Economy (Khvesin, who particularly dealt with Moscow). ${ }^{26}$ Others included a representative of the Soviet foreign ministry (Neymann), an academic, the managers of a flour mill and a senior building trade unionist. ${ }^{27}$

The non-Soviet interviewees comprised British engineers and other foreign experts working in the Soviet Union. These included employees of the Manchester-based MetropolitanVickers (Metrovick) electrical engineering company (Burt, Buckell and Tustin) which had a major role, with other Western companies, in the electrification of the Soviet Union. ${ }^{28}$ As an important Manchester industrialist, Ernest already had good links with this company. Several Sundays were spent socially with Metrovick representatives or at the company's dacha outside Moscow. Also interviewed were four central European modernist architects working in Moscow (Wilhelm Schütte, Grete Schütte-Lihotzky, François Sammer and Hans Schmidt). ${ }^{29}$ So too were various western journalists (including Maurice Hindus, RussianAmerican writer) and commercial representatives (amongst them Spencer Williams, Head of the American-Russian Chamber of Commerce in Moscow). ${ }^{30}$ Others were British Embassy staff (including the ambassador, Lord Chilston and commercial attaché, George Paton) and the American Embassy's chargé d'affaires, Loy Henderson. ${ }^{31}$

Although some Soviet printed material was secured, it was not an important source. Most information came from Soviet interviews. Some involved the whole group though others were individual. Typically they were serious and arduous affairs, each lasting 2-4 hours. ${ }^{32}$ One meeting with a very busy Soviet official began at $10 \mathrm{pm}$, extending into the early hours. ${ }^{33}$ However, since none of the visitors spoke Russian and only one interviewee spoke fluent English (and another interviewee fluent French which the group also understood), translation must have accounted for at least half of most interviews. ${ }^{34}$ Overall, Ernest felt that their Soviet interviewees had been frank and open, while clearly reflecting the official viewpoint. The group's non-Soviet interviews (most conducted in English) gave different perspectives on Soviet accounts. Although some were little more than informal chats, they clearly gave more random information. Some Western interviewees were themselves sympathetic to the Soviet system, though others were to varying degrees sceptical or critical. During the visit the group met together each night to discuss the day's discoveries and their evolving findings.

Further information came from inspecting and observing activities at relevant sites such as schools or housing blocks. Opinions of anonymous Russians (mainly in supervisory roles) at these locations were often sought. In addition, the visitors saw and, to some extent, experienced Soviet life for themselves. Its rigid inflexibilities were evident even in the opulent Metropole hotel where the group was based and still more beyond it. Ernest mentions that taking notes in public places during street walks often prompted challenges from security personnel. ${ }^{35}$ Inflexibility also took more draconian forms, directly affecting what the group saw. Thus, when the group passed construction sites on the Moscow-Volga canal where prisoner labour, under armed guard, was being used, requests to stop were denied. ${ }^{36}$ 
Other distortions could be more subtle. For example, although Ernest reckoned to have inspected fifty flats of various types, they excluded the most seriously overcrowded families. ${ }^{37}$ He estimated that roughly half Moscow families lived at less than 3 square metres per head in so-called grade IV accommodation. However, 'I did not see any of these grade IV houses; they are not normally shown to visitors, and unfortunately owing to lack of time I did not insist on seeing them. ${ }^{38}$ Nevertheless he observed the worst overcrowding in other ways, including walking outside in the evening in poorer districts. Through lighted windows, he could see barrack-style worker accommodation with many living in a large dormitory room.

\section{Effective but undemocratic planning in Moscow}

Despite the city's poor record on housing, there was much that excited Ernest about Moscow and the bold, comprehensive way its development was planned and managed. He noted his headline impressions in his unpublished diary. Breathlessly unpunctuated, occasionally illegible, his words remain unmistakeable in meaning. The visit had, he thought, been the '[m] ost thrilling 4 weeks of life at intervals quite carried away - wonderful opportunity build fine city'. ${ }^{39} \mathrm{He}$ was also impressed by the 'enthusiasm devotion unity of aim' and that the Soviet Union offered a 'good life for mass of people'. He recognised that realising the 1935 plan represented an 'immense construction job', seeing real difficulties in the lack of machines, houses and experienced workers. Yet he noted with approval that no effort was needed to fight vested interests or conservatism and was immensely impressed with those leading Moscow's reconstruction efforts.

More specifically, he saw at first-hand how public ownership of land at a stroke removed a prime obstacle to effective planning. ${ }^{40} \mathrm{He}$ also admired the absolute resolve to prevent the city (then with around 3.67 million inhabitants) overtopping 5 million. ${ }^{41}$ Admired too were the schemes to control the Moskva river, raise the water level and improve its banks; the Moscow-Volga Canal; the new Metro subway and the effort and resources devoted to all the social services. ${ }^{42}$ Above all, however, it was the vision, drive, commitment and leadership that drove the whole project that most deeply impressed him.

Later, he compared his own findings with those of other visitors, not just the Webbs. ${ }^{43}$ In the Simon party's absence, the coincidental Mossoviet visit to London in September had also prompted some British discussion about the challenges facing the two cities and their respective capacities to meet these. ${ }^{44}$ Although his first instincts were always Mancunian, Ernest incorporated some of this debate into his final thoughts in the book. He argued that Moscow was far better equipped to tackle metropolitan planning than London or any other major city in the world. His conclusion expressed the belief that, ten years on, Moscow would be well on the way to being 'the best planned great city the world has ever known' ${ }^{45}$

However he had few illusions about the USSR's negative side, fewer certainly than many other 1930s Western visitors. Despite Soviet minders, the group had learned something of the repressive system. Shena saw clearly just how mass indoctrination was occurring through the school system. ${ }^{46}$ Moreover the party had arrived just after the executions of Zinoviev and Kamenev, members of the original Bolshevik pantheon yet now, following a sham trial, 
reviled as traitors. ${ }^{47}$ Ernest was depressed at how even intelligent Soviet citizens apparently took all accusations of evil heaped on these two completely at face value. He also knew of the recent Metrovick affair when several company representatives had been detained on false charges. ${ }^{48}$ (Although naturally he did not foresee, but probably would not have been surprised, that at least two Moscow interviewees, Mezhlauk and Neymann, would soon themselves become victims of Stalinist repression). ${ }^{49}$

In the penultimate chapter of the book, Ernest asked whether the good being achieved under the Soviet system outweighed the bad. His answer conceded that, in the Russian context, it might do, provided this one-party dictatorship soon developed more democratic and less brutal tendencies. He made clear, however, that in a British context Soviet methods would be wholly unacceptable. This brought him to what was to become his overarching concern for the next few years:

'There is undoubtedly much in the powerful drive and leadership of their one-party system, and in some aspects of their socialism, that we must wholeheartedly admire and from which we must endeavour to learn...Can we achieve something of the leadership and enthusiasm while maintaining the freedom of minorities and the kindly tolerance of England? That is the problem on the solution of which the future of British democracy depends. 50

But it was not just Moscow which brought him to this point. The Simons' educational concerns had already encouraged their (especially Ernest's) wider interest in democracy and its survival in the increasingly dangerous world of the 1930s. In December 1932 he had posed the question 'Can Education save Democracy?' in an address to the Manchester Literary and Philosophical Society. ${ }^{51}$ He saw a key part of the answer in education for citizenship. With their friend Eva Hubback, the Simons had founded the Association for Education in Citizenship (AEC) in May 1934 which promoted better understanding of public affairs in schools. ${ }^{52}$ The Moscow experience then reinforced his growing belief that democracy could only start to match the decisive effectiveness of planning and governance he had seen under Communism if citizens had proper, informed understanding of public affairs.

\section{To Stockholm and Zurich}

These themes continued to resonate in Ernest Simon's thinking. In 1938, under the auspices of the AEC, he co-authored another book, Constructive Democracy. ${ }^{53}$ Led by him, a distinguished group contributed essays reflecting different shades of democratic opinion that considered the nature of democracy, the challenges to it and how they might be addressed. William Beveridge, the well-known social scientist and associate of the Webbs, examined long-term planning (including urban and regional planning) under democracy. ${ }^{54} \mathrm{He}$ concluded, as did Ernest, that it was not being well done in Britain, compared to what totalitarian states were apparently achieving. Instead, Beveridge called for the establishment of a proper organ of overall thought and forethought in public affairs that would consider and plan for future challenges and had to be consulted by government departments.

By this time, Ernest Simon was actively seeking real examples of successful democracies. This led him to new international research, reviewing how the smaller democracies of Europe, 
namely Switzerland, Sweden, Denmark, Norway and Finland, functioned. During 1938-9 he also considered the idea of a book solely on British democracy ${ }^{55}$ but felt it would be easier to reach more meaningful conclusions by examining several smaller countries than any single larger democracy. Unlike the Moscow investigation, he worked alone on this project, spending several weeks in each country during 1938 and 1939. The methodology was, however, similar to Moscow, based substantially on personal interviews. This time, however, he cited as inspiration not the Webbs but James Bryce's two-volume work Modern Democracies (which had included Switzerland though none of the others). ${ }^{56}$

The study he had in mind was much less monumental, more a thoughtful short portrait of successful small democracies that would be widely read. Originally he had hoped that Penguin might publish the resultant book. However, with writing well underway and Penguin still prevaricating, he was approached by left-wing publisher Victor Gollancz in February 1939. ${ }^{57}$ Gollancz had seen a recent letter about Sweden by Ernest in the New Statesman and wondered whether he might author a short study about the country which was being increasingly admired in progressive circles in Britain and elsewhere. But Gollancz was attracted to the wider project Ernest had in progress and quickly offered to publish it in a Left Book Club edition, ensuring a very high readership. The Smaller Democracies duly appeared as war was declared in late summer $1939 .{ }^{58}$ Earlier he had reported some findings during a British Council lecture tour of Scandinavia in November 1938 and in an article in the Journal of the Town Planning Institute in January 1939. ${ }^{59}$

Ernest began with Switzerland as his intended point of reference. Apart from Bryce's firm endorsement of the robust qualities of Swiss democracy, he already knew the country well from family links and holidaying. Following advice from his Left Book Club co-founder, John Strachey, Gollancz suggested expanding the Swedish section of the proposed book to examine unemployment policies. ${ }^{60}$ As it happened Ernest was already thinking along similar lines. He was influenced, with many others, by the American journalist Marquis Childs's notable 1936 book Sweden: The Middle Way. ${ }^{61}$ This did much to cement the growing 1930s image of Sweden as a near utopia which avoided America's capitalistic concentration and the brutal hardships of Russia. ${ }^{62}$ Ernest realised that Childs's picture was probably a little too good to be true but it certainly spurred his interest. In total, he devoted 64 pages (of 191) to Sweden.

There were other, more specific aspects of his special interest in Sweden. Familiar with the British architect-planner Clough Williams-Ellis's eulogies about the city, Ernest had from the outset wanted to examine Stockholm's housing and town planning. ${ }^{63}$ Here he felt he could investigate a case study within his own specialist field of the perceived success of Swedish democracy. He also gave some attention to urban planning in Zurich and, to a lesser extent, Bern. But in Switzerland (36 pages in the book) he focused mainly on the workings of rural local democracy and in Denmark (29 pages) on agricultural co-operatives. Norway (9 pages) and Finland (11 pages) were examined in less detail which, in the end, did not include urban planning. 
Ernest's diaries show a typically rigorous round of interviews with key figures in all these countries to gather information. Most were apparently conducted in English, with occasional ones in German. The eventual Swedish focus of the book was presaged in the approximately 35 people he interviewed in Sweden mainly during August 1938 (before Gollancz's intervention). ${ }^{64}$ They included quite senior figures in Sweden's national and local government and in academia. This compared with approximately 21 interviews in Switzerland (undated but apparently undertaken earlier in 1938), 17 in Denmark, 16 in Norway and 9 in Finland. ${ }^{65}$ Yet, although there were variations, many were shorter and less useful than those in Moscow; some were distinctly frustrating. In Stockholm, for example, he found a senior figure in the land department ( $\AA$ kerberg) 'charming and utterly incompetent' ${ }^{66}$ The even more senior real estate director (Axel Dahlberg) was 'slow - statistically unable answer any question - weak' and on land purchase he (Simon) had 'utterly failed to get any information in 45 min'. ${ }^{67}$ No sign of these frustrations appeared in the finished book. Although he claimed there was little published material, it seems that he probably discovered more from publications and written sources than in Moscow.

In both Zurich (320,000 population) and Stockholm $(560,000)$, Ernest noted how the foundations for their attractive qualities lay in their natural settings and the care city planners took to protect these. ${ }^{68} \mathrm{He}$ also noted the much less detrimental impacts of factories and railways compared to larger British towns and cities, not least because of greater electricity use. The contrast with greater British reliance on coal with attendant problems of urban smoke and grime was very marked. As in Moscow, Ernest Simon also admired the willingness and ability of both city councils to take land into public ownership. This was especially so in Stockholm's suburban fringe, where 80 per cent of land was municipally owned and values were low. ${ }^{69}$ However, he criticised the city council's timidity in the older inner city where the proportion was only 28 per cent. Despite a further 41 per cent also being state owned, the overall advantages of high public ownership were wasted and inner city land values remained very high.

The clearest single lesson he drew for British cities was how much money both Zurich and Stockholm devoted to city planning. ${ }^{70}$ Although both were smaller than either Manchester or the far larger city of London, the absolute amount each spent on their planning departments was higher; in relative terms the difference was much greater. He also admired Zurich city council's willingness to spend on cultural projects and Stockholm's to buy nearby tracts of attractive coast for recreational and holiday use. ${ }^{71}$ Yet his praise for Stockholm was not unalloyed. He felt that Manchester and other large British cities were performing better on the quality and quantity of new social housing. Admittedly housing needs in British cities exceeded those of Zurich and Stockholm. In his view, however, Bromma, a large new planned Stockholm suburb, could not match Manchester's new garden city satellite town at Wythenshawe. ${ }^{72}$

\section{The origins of the American visit}

World War II initially threw the whole question of the survival of the democratic way of life into even starker relief, especially so in the early years when there were major victories for the 
Axis powers. Over time the question shifted, especially after the Soviet Union entered the war in June 1941 and, even more, the United States in December 1941. Thereafter, it increasingly seemed that the democracies could plan the war as well as totalitarian states - but would they be as capable of planning the peace and necessary post-war reconstruction?

By the outbreak of World War II, Ernest Simon had in Stockholm and Zurich found evidence that some democratic societies at least could plan their cities effectively in the long term. They might not be perfect, but then neither was Moscow. And the important difference was that the robustly democratic character of these countries meant that governments and policies could be openly questioned and changed in a peaceful and non-violent way. What he had not established though was that larger democracies, especially the largest one of all, were capable of governing and planning effectively at an urban and regional level. At best their record, as in his own city, was patchy.

By October 1939, shortly after The Smaller Democracies was published, Ernest was proposing another investigation, specifically of local democracy in the United States. ${ }^{73}$ Bryce, writing of a period when corruption and malpractice had been particularly rife, regarded city government as the one conspicuous failure of American democracy. ${ }^{74}$ It was a view that Ernest largely shared in the late 1930s. One question he proposed probing was 'why a great democracy has allowed a state of affairs so inefficient, demoralising, and nationally humiliating, to continue. ${ }^{75}$ It was not as if there had been no efforts to address these problems. As well as Bryce, Ernest had read Leonard White's 1927 book The City Manager, essentially about using this new municipal post to strengthen city administration, improve governance and marginalise corrupt practices. ${ }^{76}$ He noted the positive things that White had said about this new role.

But when, for other reasons, he had visited the United States in 1932, he sampled expert opinions, reporting their general view that, on the whole, the city managers were 'rather a second-rate lot'. ${ }^{77} \mathrm{He}$ also noted that, even after a burst of reform to clean up any particular city and install a manager, the reformers (generally businessmen) would soon lose interest. Professional politicians would then get back and re-open the door to the old problems. And, even at their best, he felt they were hardly well-equipped for progressive, forward-looking governance in the public interest. Most city councils, he had written in 1932, 'lack vision, courage and intelligence.' The research proposal he wrote in October 1939 shows he was still thinking the same way.

For the moment, however, the national emergency meant that his proposed transatlantic visit did not materialise. After some initial hesitancy by the wartime government, Ernest's experience and talents were put to good use by the Ministries of Aircraft Production and of Works. ${ }^{78}$ In his latter role and in the wake of destruction wrought by the blitz on British cities in 1940-1, he was soon actively thinking about post-war reconstruction. The experience of his pre-war visits, to Moscow especially, took on a new relevance, even though his knowledge was now a little dated. In March 1941, he contacted several people including the Soviet ambassador in London and the British Ambassador in Moscow, in an unsuccessful attempt to discover how the 1935 plan for Moscow was progressing. ${ }^{79}$ He wanted to promote greater 
British awareness of the boldness and effectiveness of Soviet city planning and reconstruction.

The appointment in January 1941 of the Uthwatt Expert Committee on Compensation and Betterment by Lord Reith, the Minister of Works, was another spur. This Committee addressed the critical problem of how to ensure that private land ownership, especially fragmented ownership, would not frustrate public efforts to replan and reconstruct cities. Again Ernest's findings in Moscow (also, less completely, in Stockholm and Zurich) had underlined the importance of public, or at least unified, land ownership, rather than the multiple ownerships typical of British cities. By March 1941 he was pressing the British government (in the person of the Deputy Prime Minister, Labour Party leader Clement Attlee) to take action on this matter, arguing that nationalisation was the only practical step. ${ }^{80}$ Ernest understood the political difficulties but felt that war had created a fluid situation. But Attlee, as a key member of a predominantly Conservative wartime Coalition government, evidently did not consider it a politically practicable policy (either then or even later, leading his own Labour administrations after 1945).

Meanwhile apart from Ernest's day-to-day work as Deputy Chairman of the important Central Council for Works and Buildings at the Ministry of Works and Planning (as it became in early 1942), he was in various ways actively raising public awareness about post-war reconstruction. It was, for example, on this subject that he made a BBC radio broadcast in March 1942 and authored a pamphlet in September 1942. ${ }^{81}$ These and many other public initiatives by the Simons prompted the Ministry of Information to invite Ernest and Shena to do a three-month lecture tour together in the United States. ${ }^{82}$ Ernest would tell American audiences about post-war rebuilding plans in Britain while Shena would speak about its local government in wartime.

By 1942 the United States was an allied combatant nation. Via its Information Service in New York, the British government wanted to strengthen transatlantic ties. It aimed to convince a still sceptical American public opinion that, from its British bridgehead, democratic government had a viable post-war future in Europe, a counterblast to Hitler's 'New Order' for Europe. Coincidentally the tour also gave Ernest Simon the opportunity to pursue his frustrated research project on American city governance and planning. The circumstances of war obviously modified the questions to be asked, shifting them even more towards city planning. With many lecture engagements there were also limits on how much time he could devote to research.

\section{Finding (some) effective planning in democratic America}

On 19th September 1942, the Simons flew by flying boat from Ireland, via Newfoundland, to New York. ${ }^{83}$ As on his previous projects, Ernest made notes of interviews (now often informal in nature) which took place with many experts and practitioners in some fifteen cities. More than previously, however, he also used published material and reports provided by interviewees. Again, his own notes were organised in a loose leaf diary, though he subsequently removed several sections, reducing their research value. However, it seems that 
the material in question was largely incorporated (albeit with fewer incidental details) in subsequent lectures, articles, reports and a significant book, Rebuilding Britain - A Twenty Year Plan (1945). ${ }^{84}$ All these are therefore used to give a fuller picture of his American journey.

Coming straight from the privations of wartime Britain to a land of plenty, it is clear that both Simons were, from the first, entranced by many aspects of the United States. ${ }^{85}$ And, if they instantly fell for the American way of life, this infatuation was warmly reciprocated by everyone they encountered: 'Everybody instantly friendly \& interested when [they] learn [that one is] English. ${ }^{86}$ As Ernest further reflected, he '...felt popular - liked - as never before very pleasant! Why? Set out determined to like everybody - And did. ${ }^{87}$ This raises the possibility that this mutual warmth, although it certainly improved wartime Anglo-American relations, may have dulled his original critical intent. Against this, however, he still found fresh evidence of poor city governance, corruption and criminality. Of Cincinnati, long known for political jobbery, he reported the pessimism of his host, Murray Seasongood, a previous reforming mayor, that the city was rapidly reverting to older habits of corruption. ${ }^{88}$ Ernest also reported a local view of Detroit that its government was now '...pretty good. Last Mayor \& Police Chief safely in prison!'(as of 1940). ${ }^{89}$ In Salt Lake City the story was similar, while in Kansas City, the most notoriously corrupt city of all, Federal justice had finally toppled the particularly venal Pendergast regime (in 1939). ${ }^{90}$ Yet, if there were still these troubling aspects, the overall trend seemed mainly in the right direction, away from jobbery and graft.

The Simons also encountered many things they saw in a more positive light. Firmly top of this list was the Tennessee Valley Authority (TVA), the New Deal regional development project initiated by President Franklin D. Roosevelt in 1933. It had become known to some extent in 1930s Britain through the writings of the biologist, Julian Huxley and a PEP report. ${ }^{91}$ Now Ernest Simon saw it at first hand in late November 1942 and was impressed. He described it in his diary as ' $\mathrm{t}]$ he most exhilarating thing in the USA. First rate democratic planning... ${ }^{92}$ As in Moscow the quality, vision and drive of those in charge hugely impressed him - the Chairman (David Lilienthal), for example, was the 'finest type of businessman \& citizen'. In April 1943, on his return, Ernest published a short booklet about the TVA, amongst the first of several notable wartime publications about it in Britain. ${ }^{93}$ By then he had decided that it was '...probably the world's most successful experiment in large scale and long-range democratic planning., 94

As far as city planning was concerned, New York, which he visited in September and December 1942, stood out for him as the best particularly because of its express highways and parks. ${ }^{95}$ He was especially impressed with the former. Ernest was apparently (according to Robert Moses, the 'very powerful personality' largely responsible) the first Englishman to inquire seriously about the city's highways programme. In an unpublished report of December 1942 prepared to brief his own and other Ministries, Ernest wrote that New York had 'led the way' in the United States. ${ }^{96}$ Its highways and parkways were 'so good that it would seem almost essential that England should study them, especially from the point of view of the replanning of London and our other great conurbations.' He even cabled Lord Portal, Minister of Works and Planning, to this effect in early 1943 (though, by the time Portal received the 
message, planning had been moved to another Ministry). ${ }^{97}$ Back in Britain, he lobbied the Ministry of War Transport. In a wider sense, Ernest saw New York's efforts as 'probably the outstanding example of large-scale democratic city planning in the world.' Moses, he thought, was 'doing an incomparable job', even though he '[d]oes not listen' and 'knows comparatively little outside NY'. ${ }^{98}$

TVA and New York were then his two outstanding examples of democratic planning. But Ernest found many other individual things that impressed him. He admired the great traffic artery of Lake Shore Drive in Chicago, fascinated how directional lane capacity was increased or decreased by a mechanical kerb for the varying demands of morning and evening peaks. ${ }^{99}$ The City Planning Commissions recently established for many cities, particularly Los Angeles and, again, New York, were another source of particular interest for him. ${ }^{100}$ They were generally well-funded and promised much for the future. In cities as diverse as San Francisco, Denver and New Orleans, he commended the scale and quality of major public works and buildings, such as bridges and dams, parks, civic centres, railroad stations and universities. As he told an American audience in Washington in December 1942, '[a]lmost everywhere I went there were one or two outstanding achievements...[I]n imagination and drive in the really big things, we have got a great deal to learn from you'. ${ }^{101}$ Even in notoriously corrupt cities, he noted in his diary, the '[c]rooks often build well'. ${ }^{102}$

Many more general aspects of the United States also won his appreciation. He literally marvelled at the efficiency and clarity of the long distance telephone system. Nor was it just American University buildings that he commended. As Chairman of the Council of a major British University (Manchester), he wanted Britain to emulate the scale and quality of American higher education, especially its scientific and industrial research. ${ }^{103}$ As an industrialist, he appreciated the vast scale and efficiency of production at major wartime industrial facilities such as the Marinship and Kaiser shipbuilding yards in California or the Ford bomber factory at Willow Run, Michigan. ${ }^{104}$ He noted, though, how imperfectly their development was integrated with wider housing and community development.

As well as the old bad habits of municipal corruption, there were other negative aspects to city planning, for example in the absence of billboard controls in some cities, though he commended those which had taken effective action. ${ }^{105}$ Zoning ordinances were similarly uneven in their effects, from purely token restrictions imposing no actual limitation on speculative desires in some cities to really effective controls in others. He also noted the shocking prevalence of blight, especially in some cities, quite different in nature to the huge slum problems of British cities. In Detroit, for example, he noted examples close to the downtown area. Deteriorating areas, abandoned by more affluent aspirant and mobile suburbanites, had simply been left to decay and occupation by poor white and negro migrants from the South. ${ }^{106}$

\section{When British democracy rebuilds}

Yet these negative aspects did not unduly affect his overall judgements. The lessons he drew from America were mixed but mainly positive. Towards the end of a 100-day American 
journey during which Ernest had lectured 50 times about rebuilding post-war Britain and freely discussed planning with many people, he decided to write a book. He noted in his diary how much his thinking on rebuilding had cleared and improved and that 'as one contemplated Britain from a distance...comparing it with the USA; my opinion of British Democracy grew steadily more favourable! While immensely liking America. A happy experience.'107 Zigzagging slowly back to Liverpool in January 1943 in an Atlantic convoy harried by a Uboat, Ernest began to set out his thoughts in greater detail.

Once back in Britain, he continued to lecture about these themes, often referring extensively to his foreign experiences, for example to the Architectural Association annual general meeting in October 1943 and the Institute of Landscape Architects the following month. ${ }^{108}$ Earlier, in July, he had written an article for publication in Moscow on rebuilding Britain. ${ }^{109}$ By then he had also contacted Gollancz proposing a book though this only proceeded seriously the following year. ${ }^{110}$ After some production delays, Rebuilding Britain finally appeared in January 1945 in both Left Book Club and normal publisher's editions. ${ }^{111}$

In it Ernest distilled the mature lessons of his international visits. ${ }^{112}$ Some 32 pages of the book's 219 pages of narrative text were exclusively devoted to foreign examples. 23 pages were on the United States, nine on the TVA alone. Just four were devoted to Moscow, three to Zurich (and Bern) and two to Stockholm. However, to concentrate solely on this numerical balance of pages understates the role of the foreign examples in constructing the book's arguments. The last part of the book, dealing with how Britain might be rebuilt, included specific references to the experiences of these countries, used both to encourage emulation or simply for comparative purposes. Thus Moscow, 'The Planner's Paradise,' was invoked in favour of his arguments for land nationalisation and the United States for more forward-looking approaches to highways planning. ${ }^{113}$ Moscow and Zurich were drawn into a discussion about ideal city sizes. These lessons were also applied specifically to Manchester, which he urged to emulate several American and European cities by becoming a fully-fledged regional capital with fewer and better main rail terminals, more grand buildings (including a major skyscraper), and a richer cultural life. ${ }^{114}$

Rebuilding Britain was well received, selling 18,000 for the book club and around 9000 in the publisher's edition by August 1945. ${ }^{115}$ An immediate effect was that Duncan Sandys, Minister of Works since late 1944, made Ernest his housing adviser. ${ }^{116}$ The book also had some international reach, and not only in the countries Ernest had examined. In March 1945 the French Ministère de la Réconstruction et de l'Urbanisme (not yet fully decamped to postLiberation Paris) produced a cogent synopsis in French. ${ }^{117}$ The book's most distinctive feature was its emphasis, not just on physical urban and regional planning, but on detailed implementation. ${ }^{118}$ Thus Ernest examined how the necessary houses and other buildings might actually be produced (he had originally wanted to call the book 'Four Million Homes'). ${ }^{119}$ So he considered the supply of building labour, materials and land, linking physical and economic planning.

This certainly owed something to what he had seen in Moscow. But he took pains to show that this was to be democratic planning. In his conclusions, he contrasted the abundantly-funded 
command organisational structure which was successfully prosecuting the war, even in democratic countries, with how, under the Soviet system, this same structure could still be used in peacetime. ${ }^{120}$ As he commented towards the end of the book:

'... in a democracy in peace-time the people demand freedom of choice - to live, not where the Government plans, but where each individual family chooses; to criticise and to oppose with all their power anything in the government plan which may be contrary to their own interests or to their desires. ...The success of the Government in pursuing a consistent policy... will be a test of the planning powers of British democracy in times of peace. ${ }^{, 121}$

He noted that national prosperity and low interest rates would also be needed to fulfil his proposed rebuilding programme but the critical factor would, in his view, be public opinion. This formed the last section of his conclusions, where he again stressed the importance of education for democratic citizenship. He closed the book with words that echoed the spirit of his 1937 lecture: 'Let us plan and build healthy and pleasant cities, the finest the world has known, and a monument to the ideals and efficiency of British democracy'. ${ }^{122}$

\section{Discussion and conclusions}

Few planners would today use this kind of language. Even at the time, Sir Ernest Simon was unusual in so often explicitly linking urban planning to these wider themes of political values and governmental systems. A few professional town planners did speak or write this way in the 1930s and 1940s but most generally remained within a more technical discourse where political values remained implicit. Yet Ernest Simon, though widely respected within all the built environment professions, was not a professional planner. His grounding as an engineer certainly meant that he could readily relate to the technical values of the expert. But he had also absorbed the principles of welfare Liberalism and a deep commitment to the Fabian movement and its values. Added to this was an active involvement in public life, a deep commitment to urban reform and to evidence-based research interest in the quality of local governance. These attitudes, competencies and experiences meant that he was able to connect the more technical aspects of planning and the political values that underpinned them. He could also articulate that link in a cogent and engaging manner that transcended specific party interest. His more explicit language on these themes echoed much contemporary thinking, especially during World War II. The underlying thinking gave him an ideological compass to guide his international journeying.

What then might be made of Ernest Simon the 'policy tourist' and 'cross-national learner and lesson-drawer'? And what impact, in the end, did his quest for external knowledge relevant for planning a democratic society have on how actual policy discourse and action unfolded in Britain? The first point is that he was motivated essentially by self-defined reasons for visiting all the different countries. Although the Simons' American tour was, in the end, officially requested, Ernest was already by 1939 minded for other reasons to go there to undertake research. Moreover, he certainly had the wealth himself to fund these lengthy trips. So how did he decide where to seek international knowledge? There were, as shown, a mixture of motives. In choosing Moscow and Stockholm, he was certainly reflecting left-progressive intellectual 
fashions of the 1930s as both acquired iconic status in these circles. As shown, the culturallyconstructed 'imaginative geographies' of the countries of which these cities were the capitals reflected a combination of Western wishful thinking with, in the case of the Soviet Union, carefully orchestrated 'showcasing'. This was true only to a very limited extent of Switzerland, a country Ernest already knew. He also had previous experience of the United States which had left him with a rather negative image of American local democracy.

In visiting these places, however, Ernest did not go simply to confirm prior expectations, in familiar touristic fashion. Despite obvious excitement about how boldly the Soviet capital was being governed and planned, his findings were nuanced. He could extol Mossoviet's effectiveness in metropolitan governance (though recognising its deficiencies in giving decent housing to Muscovites) but be deeply unhappy with the Soviet Union's repressive aspects. Even Stockholm, superb though its planning was, left him less impressed with its housing policies than those of Manchester. As regards the United States, however, he returned far more admiring than he had anticipated. Some, though certainly not all, of this positivity stemmed from a wider captivation with much of American life, especially compared to wartime Britain. Some also came from the Simons' actual mission which was emphatically to strengthen transatlantic bonds, setting a mood of close mutual engagement with all things American. They returned with a sense that the United States truly was, at its best, a powerhouse of democracy, actively planning for its future. He obviously grasped that in many places it fell short, where individual city governments (even if no longer as corrupt as formerly) remained too willing to appease private real estate or other interests. But, beyond this, lay other aspects to which he seemed oblivious. The great racial inequality of American democracy passed without comment, noted as a symptom of urban blight but seemingly accepted as an immanent fact of nature.

Despite these occasional silences, he was in many respects the textbook 'cross-national learner and lesson-drawer'. His methodology and sheer dedication of his objective evidence-gathering were impressive. He probed deeper than most contemporary visitors into all the places he visited, combining numerous interviews with many site visits and significant reading, where written material was available. His detailed knowledge and experience of many urban policy matters meant that he was always a shrewd questioner and perceptive observer. Thus he could deploy his engineering and business brain to calculate key indicators on matters such as construction productivity or unit costs when interviewees were vague or evasive. This was especially so in Moscow where direct questioning often failed to deconstruct the official 'line' being presented.

Amidst the very intense circulation of policy information during the later 1930s and 1940s, the specific impact of Ernest Simon's exogenous knowledge on British policy discourse and action is obviously difficult to isolate. His position within but not centrally part of the government machine in the war years gave him easy access to many decision makers. There is ample evidence that he was listened to and taken seriously within government, the professions and more widely. In part, of course, this reflected his purely British experience of local government in the fields of housing and town planning. Yet, by being able also to speak with such authority about the experiences of other countries in these fields, especially those three (the Soviet Union, United States and Sweden) which were being seen as alternative possible future 
scenarios for Western democracy, he was bringing something quite unique to the policy debate. Here were actual cases of cities being more effectively planned than in Britain because more resources were devoted to planning, land was more effectively controlled for public purposes and more decisive approaches were being taken towards key determinants of the efficiency and wider quality of urban life. A part of the post-war determination to create a stronger British planning system certainly fed on such knowledge.

Creating that stronger system was to be the work of others, however. Ernest Simon's own active role within urban planning largely ended after 1945. His remarkable talents and commitment to public service were now largely deployed in governing the University of Manchester and the BBC. ${ }^{123}$ Yet he continued in both settings to be deeply aware of their roles in strengthening democracy. Nor did he ever lose his habit of seeking and drawing lessons from relevant foreign experiences.

\section{Caption}

Figure 1: Ernest Simon c1930

\section{References}

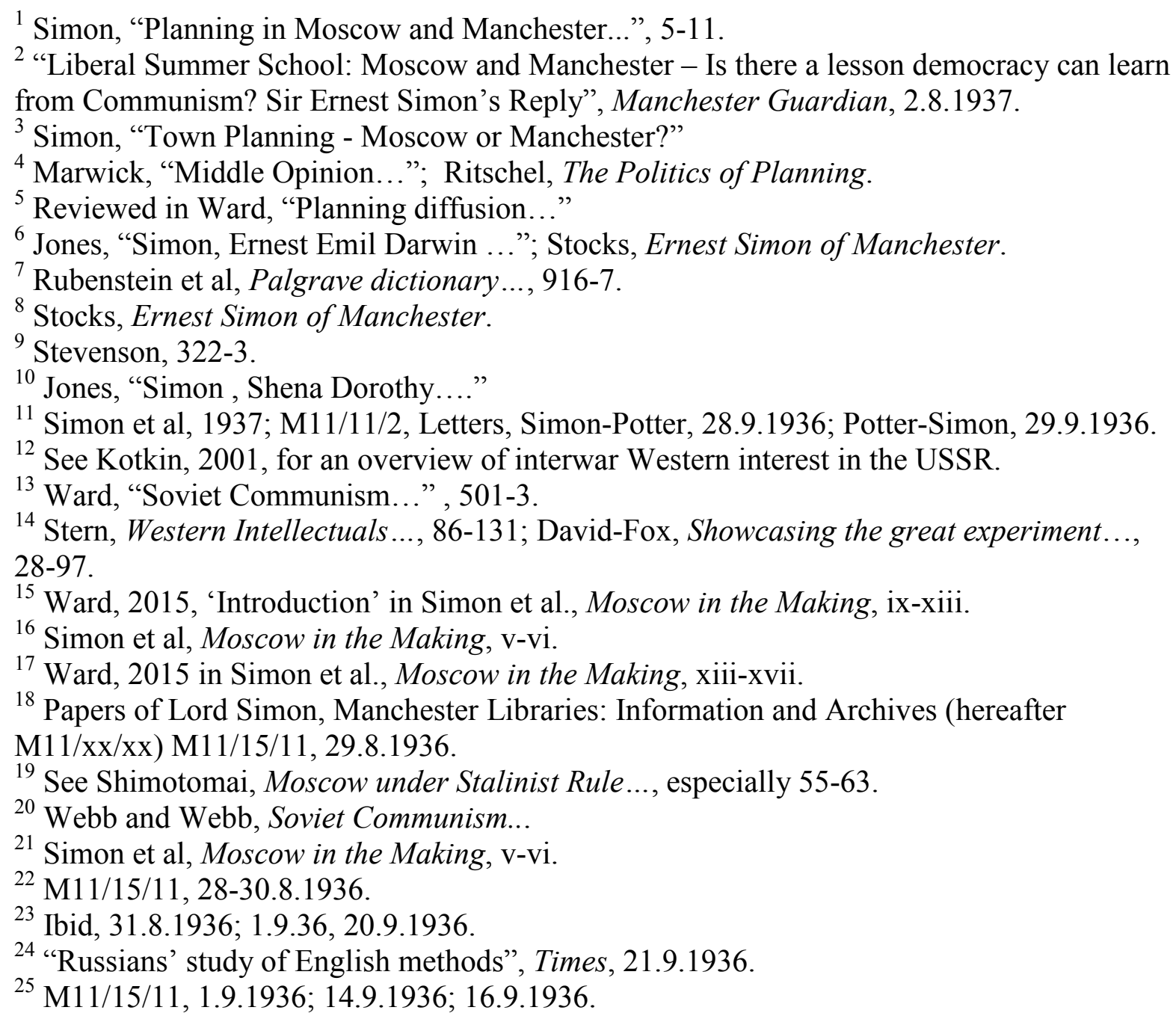


${ }^{26}$ Ibid, 4.9.1936; 5.9.1936; 23.9.1936; 25.9.1936.

${ }^{27}$ Ibid, 4.9.1936; 7.9.1936; 8.9.1936; 20.9.1936; 22.9.1936.

${ }^{28}$ Ibid, 2.9.1936; 6.9.1936; 12.9.1936.

${ }^{29}$ Ibid, 11.9.1936; 14.9.1936; 16.9.1936.

${ }^{30}$ Ibid, 13.9.1936; 15.9.1936; 19.9.1936.

${ }^{31}$ Ibid, 2.9.1936; 5.9.1936.

${ }^{32}$ Simon et al, Moscow in the Making, v-vi.

${ }^{33} \mathrm{M} 11 / 15 / 11,14.9 .1936$.

${ }^{34}$ Simon, Moscow in the Making, vi; M11/15/11, 4.9.1936; 5.9.1936.

${ }^{35}$ Ibid, 224.

${ }^{36}$ Ibid, 224-5.

${ }^{37}$ Ibid, 147.

${ }^{38}$ Ibid , 153 .

${ }^{39} \mathrm{M} 11 / 15 / 11,21$

${ }^{40}$ Simon et al, Moscow in the Making, 212-3.

${ }^{41}$ Ibid, 199-201; Shimotomai, Moscow under Stalinist Rule... , 7.

${ }^{42}$ Simon et al, Moscow in the Making, 203-6; 229-31.

${ }^{43}$ Ibid, 183.

${ }^{44}$ Editorial, Town and Country Planning, IV (14), 43-5; Simon et al, Moscow in the Making, 232-3.

${ }^{45}$ Simon et al, Moscow in the Making, 234.

${ }^{46}$ Ibid, 1937, 137-142.

${ }^{47}$ M11/15/11, 28.8.1936.

${ }^{48}$ Shimotomai, Moscow under Stalinist Rule... , 92-3; Morrell, 1995.

${ }^{49}$ Neither were actually Mossoviet members, who survived the great purge largely unscathed.

See Shimotomai, 1991, 144.

${ }^{50}$ Simon et al, Moscow in the Making, 227.

${ }^{51}$ Stocks, Ernest Simon of Manchester, 103-11.

${ }^{52}$ Hulme, 2015 discusses this more fully in the Manchester context.

${ }^{53}$ Simon et al, Constructive Democracy.

${ }^{54}$ Beveridge, "Planning under democracy" in Ibid, 125-43.

${ }^{55} \mathrm{M} 11 / 17 / 6$.

${ }^{56}$ Bryce, Modern Democracies, I, 327-454.

${ }^{57}$ M11/11/2, Letters Gollancz-Simon, 9.2.1939; Simon-Gollancz, 11.2.1939.

${ }^{58}$ Simon, The Smaller Democracies.

${ }^{59}$ M11/17/4, Scandinavian Speech, 12.11.1938; Simon, "Town Planning in Stockholm”.

${ }^{60}$ M11/11/2, Letters Gollancz-Simon, 20.2.1939; Simon-Gollancz, 1.1.1939.

${ }^{61}$ Childs, Sweden: The Middle Way; Simon, The Smaller Democracies, 52.

${ }^{62}$ Musial, Tracing Roots of the Scandinavian Model...

${ }^{63}$ Simon, "Town Planning in Stockholm", 81; Simon, The Smaller Democracies, 89-90.

${ }^{64} \mathrm{M} 11 / 15 / 13$, generally.

${ }^{65}$ M11/15/14; M11/15/9; M11/15/12, generally.

${ }^{66} \mathrm{M} 11 / 15 / 13,19$.

${ }^{67} \mathrm{Ibid}, 2$.

${ }^{68}$ Simon, The Smaller Democracies, 33-9; 89-114.

${ }^{69}$ Simon, "Town Planning in Stockholm", 82-4.

${ }^{70}$ Simon, The Smaller Democracies, 35; 91.

${ }^{71}$ Ibid, 35-7; 95.

72 Ibid, 94; 97. 
${ }^{73} \mathrm{M} 11 / 10 / 1$, USA local government...

${ }^{74}$ Bryce, Modern Democracies, II, 97-140.

${ }^{75}$ M11/10/1, USA local government...

${ }^{76}$ White, The City Manager.

${ }^{77}$ M11/10/1, The City Manager.

${ }^{78}$ Stocks, Ernest Simon of Manchester, 114-8.

${ }^{79}$ M11/11/2, Letters, Simon-Cripps, 4.3.1941; Simon-Maisky, 5.3.1941; Maisky-Simon, 7.3.1941; Cripps-Simon, 24.3.1941; Simon-Cholerton, 22.4.1941.

${ }^{80}$ M11/11/2, Letter Simon-Attlee, 19.3.1941.

${ }^{81}$ M11/16/15, Broadcast, 22.2.1942; Simon, The Rebuilding of Britain.

${ }^{82}$ Stocks, Ernest Simon of Manchester, 118.

${ }^{83} \mathrm{M} 11 / 15 / 15,1$.

${ }^{84}$ Simon, Rebuilding Britain...

${ }^{85} \mathrm{M} 11 / 15 / 15,1 ; 3$.

${ }^{86}$ Ibid, 11.

${ }^{87}$ Ibid, 12.

${ }^{88}$ Ibid, 2 (19.10.1942).

${ }^{89}$ Ibid, 2 (20.10.1942).

${ }^{90}$ Ibid, 38 (10.11.1942); 5; 36 (3.11.1942).

${ }^{91}$ Huxley, "TVA, a great American experiment", Times, 22 \& 22.5.1935 ; PEP, “The

Tennessee Valley Authority"

${ }^{92}$ M11/15/15, 9-10 (29.11.1942; 30.11.1942).

${ }^{93}$ Simon, The Tennessee Valley Authority; Huxley, TVA: Adventure in Planning; Lilienthal,

TVA: Democracy on the March.

${ }_{95}^{94}$ Simon, The Tennessee Valley Authority, 1; Ekbladh, 2002.

${ }^{95} \mathrm{M} 11 / 15 / 15,10 ; 76$ (10.12.1942).

${ }^{96}$ M11/10/1, Express Highways in the United States (19.12.1942).

${ }^{97}$ Simon, 1943, 63.

${ }^{98} \mathrm{M} 11 / 15 / 15,76(10.12 .1942)$.

${ }^{99}$ Simon, 1943, 62.

${ }^{100} \mathrm{M} 11 / 15 / 15$, passim.

${ }^{101} \mathrm{M} 11 / 10 / 1$, War, housing and post-war planning, 8 .

${ }^{102} \mathrm{M} 11 / 15 / 15,11$.

${ }^{103} \mathrm{M} 11 / 15 / 15,9,13$.

${ }^{104} \mathrm{M} 11 / 15 / 15,9 ; 10 ; 50$.

${ }^{105}$ Simon, Rebuilding Britain ..., 151-2.

${ }^{106} \mathrm{M} 11 / 15 / 15,50(18.10 .1942)$.

${ }^{107} \mathrm{M} 11 / 15 / 15,12$.

${ }^{108}$ Simon, 1943; M11/11/2, Simon, Address to Landscape Architects, 8.11.1943.

${ }^{109}$ M11/11/2, Simon, Rebuilding Britain, 20.7.1943.

${ }^{110}$ M11/11/2, Letters, Simon-Gollancz, 1.5.1943; 24.3.1944; Gollancz-Simon, 5.5.1944.

${ }^{111}$ M11/11/2, Letter Gollancz-Simon, 9.10.1944, Horsman-Simon, 25.10.1944; Simon-

Gollancz, 3.4.1945; Gollancz-Simon, 5.4.1945.

${ }^{112}$ Simon, Rebuilding Britain ..., 127-62.

113 Ibid, 171; 172-8.

114 Simon, Rebuilding Britain...,194-211, especially 203-7.

${ }^{115}$ M11/11/2, Letter Horsman-Green, 7.7.1945

${ }^{116}$ Ibid, Letter Simon-Gollancz, 3.4.1945.

${ }^{117}$ Ibid, Letter Girard-Simon, 23.5.1945; Ministère de la Réconstruction ..., Étude no. 51A. 
${ }^{118}$ Simon, Rebuilding Britain ..., 15-66; M11/11/2, Letter Williams-Ellis-Simon, 5.10.1944; 9.10.1944; Simon-Williams-Ellis, 10.10.1944.

${ }^{119}$ M11/11/2, Letter Simon-Gollancz, 17.6.1944; Gollancz-Simon, 21.6.1944; SimonGollancz, 24.8.1944.

${ }^{120}$ Simon, Rebuilding Britain ..., 227-9.

${ }^{121}$ Ibid, 231-2.

122 Ibid, 233.

${ }^{123}$ Stocks, Ernest Simon of Manchester, 124-39.

\section{References}

Bryce, J. Modern Democracies, New York: Macmillan, 1921.

Childs, M. W. Sweden: The Middle Way, New Haven: Yale University Press, 1936.

David-Fox, M. Showcasing the Great Experiment: Cultural Diplomacy and Western Visitors to the Soviet Union, 1921-1941, New York: Oxford University Press, 2012.

Ekbladh, D. “ 'Mr TVA': Grass-Roots Development, David Lilienthal, and the Rise and Fall of the Tennessee Valley Authority as a Symbol for U.S. Overseas Development, 1933-1973", Diplomatic History, 26.3, 2002, 335-74.

Hulme, T. "Putting the City Back into Citizenship: Civics Education and Local Government in Britain, 1918-45”, Twentieth Century British History, 26.1, 2015, 26-51.

Huxley, J. TVA: Adventure in Planning, Cheam: Architectural Press, 1943.

Jones, B. 'Simon, Ernest Emil Darwin, first Baron Simon of Wythenshawe (1879-1960)', Oxford Dictionary of National Biography, Oxford: Oxford University Press, 2004.

Jones, B. 'Simon, Shena Dorothy, Lady Simon of Wythenshawe (1883-1972)', Oxford Dictionary of National Biography, Oxford: Oxford University Press, 2004.

Kotkin, S. "Modern Times: The Soviet Union and the Interwar Conjuncture", Kritika: Explorations in Russian and Eurasian History, 2.1, 2001, 111-64.

Lilienthal, D. E. TVA: Democracy on the March, Harmondsworth: Penguin, 1944.

Marwick, A. "Middle Opinion in the Thirties: Planning, Progress and 'Political Agreement"”, English Historical Review, 79.311, 1964: 285-98.

Morrell, G. W. Britain Confronts the Stalin Revolution: Anglo-Soviet Relations and the Metro-Vickers Crisis, Waterloo: Wilfred Laurier University Press, 1995.

Musial, K. Tracing Roots of the Scandinavian Model. Image and Progress in the Era of Modernisation, Berlin: Humboldt-Universität zu Berlin, 1998. [https://www2.huberlin.de/skan/gemenskap/inhalt/publikationen/arbeitspapiere/ahe_17.html accessed 9 Sep 2016]. 
PEP, “The Tennessee Valley Authority”, Planning, 76, 1, 1936, 1-16.

Ritschel, D. The Politics of Planning: The Debate on Economic Planning in Britain in the 1930s, Oxford: Clarendon, 1997.

Rubinstein, W.D., Jolles, M. and Rubinstein, H. L. (eds) (2011) Palgrave Dictionary of Anglo-Jewish History, Basingstoke: Palgrave.

Shimotomai, N. Moscow under Stalinist Rule, Basingstoke: Macmillan, 1998.

Simon, E. “Town Planning: Moscow or Manchester?" Journal of the Town Planning Institute, 23.12, 1937: 381-9.

Simon, E. "Planning in Moscow and Manchester Compared", Report of the Town and Country Planning Summer School, London: Harrison for TCPSS, 1937: 5-11.

Simon, E., Halifax, Viscount., Bryant, A. Bassett, R., Lothian, Marquess of., Attlee, C. R., Beveridge, W. et al. Constructive Democracy, London: Allen and Unwin, 1938.

Simon, E. "Town Planning in Stockholm", Journal of the Town Planning Institute, 25.3, 1939: 81-5.

Simon, E. The Rebuilding of Britain, Manchester: Privately printed, 1942.

Simon, E. The Tennessee Valley Authority, Manchester: privately printed, 1943.

Simon, E. Constructive Democracy, London: Allen and Unwin, 1938.

Simon, E. D. The Smaller Democracies, London: Left Book Club, 1939.

Simon, E. D. Rebuilding Britain - A Twenty Year Plan, London: Left Book Club, 1945.

Simon, E. D., Simon, S. D., Robson, W. A. and Jewkes, J. Moscow in the Making, London, Longmans Green, 1937.

Stern, L. Western Intellectuals and the Soviet Union, 1920-40: From Red Square to Left Bank, Abingdon: Routledge, 2007.

Stevenson, J. British Society 1914-45, Harmondsworth: Penguin, 1984.

Stocks, M. Ernest Simon of Manchester, Manchester: Manchester University Press, 1963.

Ward, S. V. "Soviet Communism and the British Planning Movement: rational learning or Utopian imagining?” Planning Perspectives 27.4, 2012: 499-524.

Ward, S. V. "Planning Diffusion: Agents, Mechanisms, Networks and Theories", in C. Hein (ed) Handbook of Planning History, New York: Routledge, 2017 (forthcoming).

Webb, S. and Webb, B. Soviet Communism: A new civilisation? 2 vols, London: Longmans, Green, 1935. 
White, L. D. The City Manager, Chicago: University of Chicago Press, 1927. 